\title{
Evaluation of the reproductive performance of rabbits does fed a half- simplified diet based on cassava byproducts
}

\author{
Andréia Fróes Galuci Oliveira ${ }^{1}$, Cláudio Scapinello ${ }^{1}$, Meiby Carneiro de Paula Leite ${ }^{2}$, Ana \\ Carolina Monteiro Motta ${ }^{1}$, Josianny Limeira Figueira ${ }^{1}$, Fernanda Catelan ${ }^{1}$, Marciana Retore ${ }^{1}$ \\ 1 Departamento de Zootecnia - Universidade Estadual de Maringá. \\ 2 Departamento de Zootecnia - Universidade Federal do Recôncavo da Bahia.
}

\begin{abstract}
A total of 70 five-month-old female New Zealand White rabbits were assigned in a completely randomized design, over three reproductive cycles, with two treatments: a reference diet and a half-simplified diet containing $79.83 \%$ cassava byproduct. The study evaluated body weight and feed intake of does, feed cost, number and total body weight of kits at kindling and weaning per female during three cycles, number and percentage of mortality/female/cycle, and weight gain of kits from birth to weaning. No interaction was observed between the diets and among the reproductive cycles for any evaluated characteristics. The body weight of does at the moment of weaning was similar in both groups for all three reproductive cycles. However, does fed the half-simplified diet had lower feed intake during the three reproductive cycles and, consequently, more reproductive flaws. The number of kits at weaning, body weight of kits at kindling and weaning, weight gain of kits from birth to weaning, and total body weight of kits at weaning were lower for the group of does fed the half-simplified diet and, consequently, there was a higher number and percentage of dead kits in this group. The total numbers of kits at kindling and weaning and total body weight of kits at birth during all three reproductive cycles were similar between the groups; however, total body weight of weaning rabbits was higher for the animals receiving the reference diet. It is possible to conclude that although the use of the half-simplified diet decreases the reproductive performance of does, it reduces feed cost per kg of body weight by $23.63 \%$ compared with the reference diet, proving to be a viable nutritional option for rabbit production.
\end{abstract}

Key Words: cassava meal, hay from the upper third of cassava foliage, reproduction

\section{Introduction}

Feeding accounts for approximately $70 \%$ of production costs in animal raising systems. The majority of feed types used in animal nutrition are based on ingredients such as corn and soybeans, which compete directly with human feeding and have high market costs (Silva et al., 2000). For rabbit diets, roughage sources are included as well, accounting for $35 \%$ to $40 \%$ of diet volume. Among these sources is alfalfa hay, which is a dietary source of high cost and limited availability (Scapinello et al., 2003).

Brazil is the biggest producer of cassava in the American continent. Even though production has not increased in recent years, more than 26 million tons were harvested annually in 2007 and 2008 (IBGE, 2009). The search for alternative feedstuffs for use in animal diets should be a constant concern for researchers focusing on animal production.

Given that rabbits make efficient use of vegetable protein, the aerial part of cassava, in addition to providing fiber components, also allows a reduction in the level of protein-rich concentrated food items such as soybean meal, thereby reducing the cost of formulations.
Conversely, cassava roots have high starch content, representing an important energy source as well as being palatable and able to be included in the diets of all domestic animals (Ferreira Filho et al., 2004). Using the aerial part and roots or their byproducts therefore provides significant volumes of protein, fiber and energy in the formulations of rabbit feed.

Half-simplified diets for rabbits, formulated with high inclusion of forage or agroindustrial byproduct, emerged in an attempt to combine maximum savings and satisfactory animal performance.

This research was carried out to evaluate the use of a half-simplified diet based on cassava byproducts, representing $79.83 \%$ of diet volume, on the reproductive performance of female New Zealand White rabbits over three reproductive cycles.

\section{Material and Methods}

The experiment was carried out at the rabbit breeding sector of Fazenda Experimental do Iguatemi of the Universidade Estadual de Maringá (UEM), Paraná State, 
Brazil, between February and October 2007, with low temperatures averaging $19.7^{\circ} \mathrm{C}$, average maximum of $26.0^{\circ} \mathrm{C}$ and average relative humidity of $63 \%$.

A total of 70 New Zealand White does was used, during three reproductive cycles, with average initial age of five months and servicing for the first time at 6 months of age. Does were housed individually in galvanized wire cages featuring automatic water dispensers and semi-automatic feeders, set inside a shed covered with corrugated asbestos roofing, $3.8 \mathrm{~m}$ high, solid flooring, 30-cm masonry side wall, and the remainder in mesh and plastic curtaining for wind control. Prior to first servicing, does were allotted in two groups and fed the experimental diets during 30 days.

The experimental design was completely randomized, with two treatments: a reference diet and a half-simplified feed containing cassava byproducts in which cassava root meal (40\%) and hay from the upper third of cassava foliage (39.83\%) accounted for $79.83 \%$ of roughage. Feeds were balanced to meet the nutritional requirements for breeding animals (Table 1), according to De Blas \& Wiseman (1998).

Feeds were dry-pelletized in a Chavantes-brand pellet mill, 40 HP model, 800-1700-kg/hour capacity, 4.5-mm die holes, without added steam.

Feed and water were provided ad libitum, except for does with reproductive problems and outside the lactation period, which received only $120 \mathrm{~g}$ daily to avoid overweight.

The cassava variety (Manihot esculenta Crantz) used to produce the hay was Fécula Branca, also known in Brazil as Santa Helena, at 19 months. The upper third of the aerial part was collected directly in the field, in the region of Cianorte and Paranavaí (PR). The collected material was chopped into pieces smaller than $2 \mathrm{~cm}$, using a forage chopper. The resulting material was then spread over a cement floor, turned over twice a day during three days until dry, resulting in hay from the upper third of cassava foliage. It was later baled and stored in a dry and ventilated environment until the time of use, when it was ground for inclusion in the feed.

The male:female reation was 1:5. Females were serviced in the morning, with repeated servicing in the late afternoon, always with the same buck as before. Ten days after kindling, does were serviced again, by taking the female to the male's cage, thereby starting a new reproductive cycle. Whenever the doe did not accept the buck, mating was forced. Females were examined ventrally 17 days after service, and those that failed were serviced again.

For cost analysis, the prices of the ingredients used in the feeds were collected in the region of Maringá, Paraná state, in April 2010 at a US dollar exchange rate of 1.7690 Reals and Euro rate of 2.4041 Reals: corn, R\$ 0.34/kg;
Table 1 - Composition of the experimental diets

\begin{tabular}{|c|c|c|}
\hline \multirow[t]{2}{*}{ Ingredient (\%) } & \multicolumn{2}{|c|}{ Diet } \\
\hline & Reference & $\begin{array}{c}\text { Half- } \\
\text { simplified }\end{array}$ \\
\hline Ground corn & 25.78 & - \\
\hline Wheat bran & 24.00 & - \\
\hline Alfalfa hay & 16.65 & - \\
\hline Coast-cross hay & 16.42 & - \\
\hline & \multicolumn{2}{|c|}{ of cassava foliage ${ }^{1}$} \\
\hline Cassava root meal ${ }^{1}$ & - & 39.00 \\
\hline Soybean meal $45 \%$ & 14.30 & 17.00 \\
\hline Dicalcium phosphate & 0.50 & 1.40 \\
\hline Lime & 1.20 & 0.60 \\
\hline Salt & 0.40 & 0.40 \\
\hline Mineral mix + vitamin ${ }^{2}$ & 0.50 & 0.50 \\
\hline DL-methionine & 0.12 & 0.16 \\
\hline L-lysine HCL & 0.10 & 0.08 \\
\hline Cycostat ${ }^{\circledR 3}$ & 0.03 & 0.03 \\
\hline \multicolumn{3}{|c|}{ Chemical composition, dry matter basis (\%) } \\
\hline Dry matter ${ }^{4}$ & 90.36 & 90.48 \\
\hline Crude protein ${ }^{4}$ & 16.83 & 17.18 \\
\hline Acid detergent fiber ${ }^{4}$ & 18.48 & 22.89 \\
\hline Neutral detergent fiber ${ }^{4}$ & 33.06 & 27.50 \\
\hline Crude fiber 5 & 13.00 & 13.00 \\
\hline Calcium $^{5}$ & 1.00 & 1.00 \\
\hline Total phosphorus ${ }^{5}$ & 0.50 & 0.50 \\
\hline Methionine + cysteine $^{5}$ & 0.60 & 0.60 \\
\hline Total lysine ${ }^{5}$ & 0.80 & 0.80 \\
\hline Digestible energy $(\mathrm{kcal} / \mathrm{kg})$ & 2.600 & 2.600 \\
\hline Starch $^{4}$ & 18.00 & 27.00 \\
\hline Cost/kg (R\$) & 0.62 & 0.53 \\
\hline \multicolumn{3}{|c|}{$\begin{array}{l}{ }^{1} \text { The value for digestible energy of hay from the upper third of cassava foliage and } \\
\text { cassava root meal was based on results by Michelan et al. (2006), and the other } \\
\text { nutrients (except for cassava byproducts) according to De Blas \& Wiseman } \\
\text { (1998). }\end{array}$} \\
\hline \multicolumn{3}{|c|}{$\begin{array}{l}2 \text { Nuvital, composition per kg of product: vit. A - 600,000 IU; vit. D - 100,000 IU, } \\
\text { vit. E - 8,000 mg; vit. } \mathrm{K}_{3}-200 \mathrm{mg} \text {; vit. } \mathrm{B}_{1}-400 \mathrm{mg} \text {; vit. } \mathrm{B}_{2}-600 \mathrm{mg} \text {; vit. } \mathrm{B}_{6} \\
200 \mathrm{mg} \text {; vit. } \mathrm{B}_{12}-2,000 \mathrm{mcg} \text {; pantothenic acid - 2,000 mg; choline - 70,000 mg; } \\
\text { iron - 8,000 mg; copper - } 1,200 \mathrm{mg} \text {; cobalt - } 200 \mathrm{mg} \text {; manganese - } 8,600 \mathrm{mg} \text {; zinc } \\
\text { 12,000 mg; iodine - } 64 \mathrm{mg} \text {; selenium - } 16 \mathrm{mg} \text {; methionine - } 120,000 \mathrm{mg} \text {; } \\
\text { antioxidant - 20,000 mg. }\end{array}$} \\
\hline
\end{tabular}

soybean meal, $\mathrm{R} \$ 0.87 / \mathrm{kg}$; wheat bran, $\mathrm{R} \$ 0.35 / \mathrm{kg}$; hay from the upper third of cassava foliage, R\$ $0.40 / \mathrm{kg}$; alfalfa hay, $\mathrm{R} \$ 1.00 / \mathrm{kg}$; coast-cross hay, R $0.37 / \mathrm{kg}$; cassava root meal, $\mathrm{R} \$ 0.24 / \mathrm{kg}$; common salt, $\mathrm{R} \$ 0.38 / \mathrm{kg}$; lime, $\mathrm{R} \$ 0.18 / \mathrm{kg}$; lysine, R\$ 7.32/kg; dicalcium phosphate, R\$ 2.34/kg; vitamin and mineral supplement, R\$ 8.85/kg; methionine, R \$22.00/kg; coccidiostat (Cycostat), R \$11.31/kg; soybean oil, R\$3.00/kg; and BHT, R \$ 7.00/kg.

Two days before kindling, nests were placed inside the doe cages, where they remained until kits were 20 days old. During the time that nests remained inside the cages, daily inspections were made to maintain adequate conditions during that physiological stage.

The assessments of dry matter (MS), crude protein (PB), neutral detergent fiber (NDF), acid detergent fiber $(A D F)$ and gross energy (EB) of the ingredients and feeds 
were carried out according to the description by Silva \& Queiroz (2002), and diet starch according to Pereira \& Rossi (1995), at the Laboratório de análises de alimentos e nutrição animal of the Universidade Estadual de Maringá; the rates of total polyphenols in the hay from the upper third of cassava foliage and cassava root meal were assessed according to the methodology by Horwitz (2005); levels of hydrocyanic acid (HCN) in the hay from the upper third of cassava foliage and cassava root meal (Table 2) were obtained according to the methodology of Horwitz (1975) and analyzed at the Instituto de Tecnologia de Alimentos (ITAL) in Campinas, PR.

For analysis of reproduction-related traits, the following were evaluated: doe weight at first service and at weaning; total feed intake and within each cycle by does; number and weight of kits born and weaned per doe during the three cycles; average weight gain of kits from kindling to weaning; litter body weight at weaning per cycle; total number and total body weight of kits at kindling and weaning during the three reproductive cycles; and feed cost.

For the weight and number of kits at kindling, the average weight and number of live-born + stillborn animals were considered.

Statistical analyses from the studied variables were carried out using SAS statistics software (2000). All analyzed variables showed normal distribution and were thus submitted to analysis of variance, using doe weight at first service as co-variable.

The statistical model used to analyze doe-related characteristics during the three reproductive cycles was:

$$
\mathrm{Y}_{\mathrm{ij}}=\mu+\mathrm{b}_{1}\left(\mathrm{x}-\mathrm{x}_{\mathrm{m}}\right)+\mathrm{Ri}+\mathrm{e}_{\mathrm{ij}}
$$

in which: $Y_{i j}=$ observation regarding doe weight, doe feed intake and number of kits born and weaned per doe during the three cycles, fed diet $\mathrm{i} ; \mu=$ overall constant; $\mathrm{b}_{1}=$ linear regression coefficient of variable $\mathrm{x}$; $\mathrm{x}=$ doe body weight at first service; $\mathrm{x}_{\mathrm{m}}=$ average doe body weight at first service; $\mathrm{Ri}=$ effect of diet $\mathrm{i}$, with $\mathrm{i}_{1}=$ reference diet, $\mathrm{i}_{2}=$ half- simplified feed; $\mathrm{e}_{\mathrm{ij}}=$ random error associated with each observation.

The statistical model used to analyze doe-related characteristics per reproductive cycle was:

$$
Y_{i j k}=\mu+b_{1}\left(x-x_{m}\right)+R_{i}+C_{j}+R C_{i j}+A_{k} / R_{i}+e_{i j k}
$$
in which: $Y_{i j k}=$ observation regarding the number of born, dead, weaned kits, mortality rate; body weight of kits born and weaned/doe/cycle fed diet $\mathrm{i} ; \mu=$ overall constant; $\mathrm{b}_{1}=$ linear regression coefficient of variable $\mathrm{x}$; $\mathrm{x}=$ doe body weight at first service; $\mathrm{x}_{\mathrm{m}}=$ average doe body weight at first service; $\mathrm{R}_{\mathrm{i}}=$ effect of diet $\mathrm{i}$, with $\mathrm{i}_{1}=$ reference diet, $\mathrm{i}_{2}=$ halfsimplified feed; $\mathrm{C}_{\mathrm{j}}=$ cycle effect, with $\mathrm{j}_{1}=$ cycle $1, \mathrm{j}_{2}=$ cycle 2 and $\mathrm{j}_{3}=$ cycle $3 ; \mathrm{RC}_{\mathrm{ij}}=$ interaction effect between diet and reproductive cycle; $A_{k} / R_{i}=$ effect of animal k receiving diet $\mathrm{i} ; \mathrm{e}_{\mathrm{ijk}}=$ random error associated with each observation.

\section{Results and Discussion}

The differences in chemical composition between the reference and half-simplified diets, particularly with regard to NDF and ADF (Table 2), were due to the characteristics of the ingredients used in their formulation, as cassava hay has less NDF and more ADF compared with the fiber contents of the reference diet.

Body weight of female rabbits during the first weaning (PVPD), second weaning (PVSD) and third weaning (PVTD) did not differ $(\mathrm{P}>0.05)$ between the females fed with the reference diet and half-simplified feed (Table 3 ).

The intake of female rabbits fed with half-simplified feed from the first service to the third weaning (Table 4 ) was lower $(\mathrm{P}<0.05)$ than that of females receiving the reference diet.

During the experimental period, females fed the halfsimplified diet usually left over scraps in the feeders, as this type of feed had harder pellets $\left(1.21 \mathrm{t} / \mathrm{m}^{3}\right.$ specific mass $)$ compared with the reference diet $\left(1.0 \mathrm{t} / \mathrm{m}^{3}\right.$ specific mass $)$, which is a factor characteristic of cases of high cassava root meal inclusion in formulations. Another aspect related to the lower intake of the half-simplified diet could be the

Table 2 - Chemical composition and percentage of total polyphenols, starch and hydrocyanic acid in the hay from the upper third of cassava foliage and cassava root meal (\%DM)

\begin{tabular}{lcc}
\hline Nutrient (\%) & \multicolumn{2}{c}{ Cassava byproduct } \\
\cline { 2 - 3 } & Hay from the upper third of cassava foliage & Cassava root meal \\
\hline Dry matter & 91.33 & 90.32 \\
Crude protein & 21.60 & 1.37 \\
Neutral detergent fiber & 52.38 & 10.29 \\
Acid detergent fiber & 42.67 & 7.38 \\
Gross energy (kcal/kg) & 4,578 & 4,258 \\
Total polyphenols & 0.38 & 0.03 \\
Hydrocyanic acid (mg/kg) & 103,2 & ND \\
\hline
\end{tabular}

$\mathrm{ND}=$ Not detected. 
presence of polyphenols in the cassava plants $(0.38 \%)$, which may affect the palatability of the diet.

Scapinello et al. (2006) evaluated the performance and carcass characteristics of rabbits, from weaning to slaughter, fed diets in which corn was gradually replaced with cassava root meal (fiber variety), and also observed lower feed intake by the animals.

The does fed the half-simplified diet showed longer intervals $(\mathrm{P}<0.05)$ between the first service and the third weaning (C1D3) compared with those that received the reference diet (Table 4). This means more unsuccessful matings for does fed the half-simplified feed, totaling $171 \pm 3.86$ days in the total experiment period, versus $159 \pm 2.96$ for females that received the reference diet. This can certainly be attributed to the lower nutrient intake to meet the nutritional needs of does kept under intense breeding schedules, as arranged in this experiment.

There was no interaction effect $(\mathrm{P}>0.05)$ between the feeds used and the three cycles evaluated on the reproductive performance of does (Table 5). The use of the half-simplified diet affected the reproductive performance of does $(\mathrm{P}<0.05)$, as kit's average body weight at birth (PVN), litter size at weaning, kit's average body weight at weaning (PVD), kit's average weight gain from birth to weaning (GND) and body weight of the litter at weaning (PVDC), per reproductive cycle, were lower $(\mathrm{P}<0.05)$ compared with the values obtained with the reference feed.

The number and percentage of dead kits from birth to weaning (NLM and LM) per reproductive cycle were higher $(\mathrm{P}<0.05)$ in the group of doe rabbits fed the half-simplified diet, possibly as a result of lower intake of the half-simplified diet and, consequently, the smaller litter size $(\mathrm{P}<0.05)$ in that group (Table 5).

Does fed the half-simplified diet ingested less feed. This lower amount was insufficient to provide the necessary nutrients to maintain the females while gestating and producing milk. Consequently, there was a higher kit mortality rate $(\mathrm{P}<0.05)$ and lower weight at kindling

Table 3 - Body weight of female rabbits during service and weaning according to experimental diets

\begin{tabular}{|c|c|c|c|c|}
\hline \multirow[t]{2}{*}{ Characteristic (g) } & \multicolumn{2}{|c|}{ Diet } & \multirow[t]{2}{*}{ General average (g) } & \multirow[t]{2}{*}{$(\mathrm{P}<0.05)$} \\
\hline & Reference & Half-simplified & & \\
\hline Body weight at first service & 3,658 & 3,658 & 3,658 & \\
\hline Body weight at first weaning & $4,002 \pm 49$ & $3,905 \pm 50$ & $3,954 \pm 36$ & NS \\
\hline Body weight at second weaning & $4,120 \pm 59$ & $4049 \pm 61$ & $4,085 \pm 42$ & NS \\
\hline Body weight at third weaning & $4,057 \pm 66$ & $4,003 \pm 67$ & $4,030 \pm 46$ & NS \\
\hline
\end{tabular}

NS = non-significant.

Table 4 - Feed intake, period (days) and feed cost for female rabbits during the full period, according to experimental diets

\begin{tabular}{|c|c|c|c|c|}
\hline \multirow[t]{2}{*}{ Period } & \multicolumn{2}{|c|}{ Diet } & \multirow[t]{2}{*}{ General average (g) } & \multirow[t]{2}{*}{$(\mathrm{P}<0.05)$} \\
\hline & Reference & Half-simplified & & \\
\hline & \multicolumn{4}{|c|}{ Intake (g) } \\
\hline \multirow[t]{2}{*}{ C1D3 } & $43,063 \pm 904 a$ & $38,478 \pm 974 b$ & $40,771 \pm 715$ & 0.0010 \\
\hline & \multicolumn{4}{|c|}{ Period (days) } \\
\hline \multirow[t]{2}{*}{ C1D3 } & $159 \pm 3.0 \mathrm{a}$ & $171 \pm 3.9 b$ & $165 \pm 2.5$ & 0.0188 \\
\hline & \multicolumn{4}{|c|}{ Feed cost per female ( $R \$)$} \\
\hline C1D3 & $26.70 \pm 539 b$ & $20.39 \pm 539 a$ & $23.55 \pm 381$ & 0.0001 \\
\hline
\end{tabular}

C1D3 - first service to third weaning.

a-b Averages in each row, for each variable, followed by different letters, are different $(\mathrm{P}<0.05)$.

Table 5 - Litter characteristics according to experimental diets and reproductive cycles

\begin{tabular}{|c|c|c|c|c|c|c|c|c|c|c|}
\hline \multirow[t]{2}{*}{ Characteristic } & \multicolumn{2}{|c|}{ Diet } & \multirow[t]{2}{*}{$(\mathrm{P}<0.05)$} & \multicolumn{5}{|c|}{ Cycle } & \multirow[t]{2}{*}{$(\mathrm{P}<0.05)$} & \multirow{2}{*}{$\begin{array}{l}\text { Overall } \\
\text { average }\end{array}$} \\
\hline & Reference & Half-simplified & & & 1 & & 2 & 3 & & \\
\hline Litter size at birth & $6.8 \pm 0.2$ & $7.0 \pm 0.3$ & 0.55 & 5.8 & $\pm 0.2 c$ & 7.0 & $\pm 0.3 \mathrm{~b}$ & $7.9 \pm 0.3 a$ & 0.01 & $6.9 \pm 0.2$ \\
\hline Litter size at weaning & $5.5 \pm 0.2 \mathrm{a}$ & $4.9 \pm 0.2 b$ & 0.04 & 4.9 & \pm 0.2 & 5.2 & \pm 0.3 & $5.4 \pm 0.3$ & 0.31 & $5.2 \pm 0.2$ \\
\hline Dead kits from kindling to weaning (no.) & $1.4 \pm 0.2 \mathrm{a}$ & $2.1 \pm 0.2 b$ & 0.01 & 0.9 & $\pm 0.1 \mathrm{a}$ & 1.7 & $\pm 0.2 b$ & $2.5 \pm 0.2 c$ & 0.01 & $1.7 \pm 0.1$ \\
\hline Dead kits from kindling to weaning (\%) & $19.8 \pm 2.2 \mathrm{a}$ & $28.4 \pm 2.5 b$ & 0.01 & 16 & $\pm 2.2 \mathrm{a}$ & 26 & $\pm 3.4 \mathrm{~b}$ & $31 \pm 2.9 b$ & 0.01 & $24.1 \pm 1.7$ \\
\hline Kit body weight at kindling (g) & $57.7 \pm 0.8 a$ & $54.4 \pm 0.9 b$ & 0.01 & 58 & \pm 0.9 & 56 & \pm 1.2 & $55 \pm 0.9$ & 0.15 & $56.1 \pm 0.6$ \\
\hline Kit body weight at weaning (g) & $708.1 \pm 0.2 \mathrm{a}$ & $592.5 \pm 13.1 b$ & 0.01 & 645 & \pm 17.3 & 665 & \pm 15.5 & $640 \pm 15.2$ & 0.39 & $650 \pm 9.2$ \\
\hline Weight gain from kindling to weaning (g) & $650.1 \pm 9.8 \mathrm{a}$ & $538.1 \pm 12.8 b$ & 0.01 & 588 & \pm 16.8 & 608 & \pm 14.8 & $585 \pm 14.8$ & 0.38 & $594 \pm 9.0$ \\
\hline Litter body weight at weaning per cycle (g) & $3,935 \pm 112.9 a$ & $2,829 \pm 199.2 b$ & 0.013 & 3,072 & $\pm 127 b$ & 3,598 & $\pm 158 \mathrm{a}$ & $3,470 \pm 162 \mathrm{a}$ & 0.013 & $3,377 \pm 87.4$ \\
\hline
\end{tabular}


compared with kits from does fed the reference feed (Table 5).

In the analysis of the effects of the reproductive cycle sequence, litter size at kindling $(\mathrm{LN})$ increased $(\mathrm{P}<0.05)$ over the successive reproductive cycles, as did NLM during the period from kindling to weaning. However, litter size, body weight at birth and at weaning, and weight gain of kits from kindling to weaning did not differ $(\mathrm{P}>0.05)$ in the three reproductive cycles. The percentage of dead kits from kindling to weaning and litter total body weight at weaning were higher $(\mathrm{P}<0.05)$ in the second and third reproductive cycles.

Similar breeding doe performance was observed by Machado et al. (2007), who evaluated simplified diets containing cassava byproducts based on hay from the upper third of cacau-variety cassava foliage and alfalfa hay for does and growing rabbits. These authors observed a reduction in the performance of does and growing rabbits after receiving cassava foliage hay. The authors commented that the material used showed extremely low nutritional value $(1,149.81 \mathrm{kcal} / \mathrm{kg}$ MS of digestible energy and $9.6 \%$ of digestible protein), thereby emphasizing the need to research cultivars with better nutritional values for this species.

Andrade (1997), however, obtained satisfactory results when evaluating different replacement levels $(0,10,20$ or $30 \%$ ) of commercial feed by cassava stem hay, cigana variety, on the reproductive performance of does. With
$30 \%$ inclusion of cassava stem hay, that author observed a higher number of kits per litter, higher mean body weight of kits at kindling and slaughter, and lower neonatal mortality and mortality during nursing.

The total number of kits born, weaned and total body weight of kits at kindling in the three reproductive cycles were similar ( $\mathrm{P}>0.05)$ among the diets; however, total body weight of weaned kits was higher $(\mathrm{P}<0.05)$ in the group fed the reference feed (Table 6).

Although the number of kits born and weaned was similar between the two groups, the total body weight of kits weaned during the three cycles, fed the reference feed was higher by $3.030 \mathrm{~kg}(\mathrm{P}<0.05)$, a difference that may have resulted from the lower feed intake and, consequently, by lower milk production by does receiving the half-simplified diet.

Despite the inferior performance of does fed the halfsimplified feed compared with those fed the reference diet, these results allowed a reduction in feeding cost (Table 4) per doe during the three reproductive cycles $(\mathrm{P}<0.05)$. The use of half-simplified diets for reproductive rabbit does proved to be viable, given that, although reproductive performance was slightly lower overall compared with traditional diets, they afforded greater savings to producers, due to the use of agroindustrial products discarded in the field or sold at low prices to producers, and which can be used in rabbit diets.

Table 6 - Doe performance characteristics according to experimental diets during the three reproductive cycles

\begin{tabular}{lrrrrr}
\hline Characteristic & \multicolumn{2}{c}{ Diet } & Overall average $(\mathrm{g})$ & \\
\cline { 2 - 3 } & Reference & Half-simplified & & \\
\hline Total kits at kindling & $20.5 \pm 0.8$ & $21.0 \pm 0.9$ & $20.7 \pm 0.6$ & 0.6826 \\
Total body weight kits at kindling (g) & $1,162 \pm 44$ & $1,107 \pm 44$ & $1,135 \pm 31$ & 0.3832 \\
Total kits at weaning & $16.4 \pm 0.7$ & $14.8 \pm 0.8$ & $15.6 \pm 0.5$ & 0.1420 \\
Total body weight kits at weaning (g) & $11,356 \pm 454 \mathrm{a}$ & $8,326 \pm 446 \mathrm{~b}$ & $9,841 \pm 365$ & $<0.0001$ \\
\hline
\end{tabular}

a-b Averages in each row, for each variable, followed by different letters, are different $(\mathrm{P}<0.05)$.

\section{Conclusions}

The use of half-simplified feed reduced the reproductive performance of does in all three reproductive cycles. Nevertheless, it reduced feed cost by $23.63 \%$ compared with the reference diet, justifying its use in breeder doe diets, particularly under conditions of less-intense reproductive cycle and more adequate to this feeding alternative.

\section{References}

ANDRADE J.O. Efeito da inclusão do feno da parte aérea de mandioca (Manihot esculenta, Crantz) na ração, sobre o desempenho reprodutivo de coelhas (Oryctolagus cuniculus) mestiças. 1997. 54f. Dissertação (Mestrado em Agronomia) Universidade Federal da Bahia, Cruz das Almas.

DE BLAS, C.; WISEMAN, J. The nutrition of the rabbit. New York: CABI Publishing, 1998. 344p.

FERREIRA-FILHO, J.R.; MATTOS P.L.P.; GOMES J.C. Raspa de mandioca na alimentação animal. Cruz das Almas: Embrapa Mandioca e Fruticultura, 2004. 4p.

INSTITUTO BRASILEIRO DE GEOGRAFIA E ESTATÍSTICA IBGE [2009]. Levantamento sistemático da produção agrícola: Pesquisa mensal de previsão e acompanhamento das safras agrícolas no ano civil. IBGE/CEPAGRO. Available on: <http://www.ibge.gov.br/home/estatistica/indicadores/ agropecuaria/lspa/> Accessed on: Aug. 2009.

HORWITZ, W. Official methods of analysis of the Association of Official Analytical Chemists. 12.ed. Gaithersburg, Maryland: AOAC, 1975. 1094p. 
HORWITZ, W. Official methods of analysis of the Association of Official Analytical Chemists. 18.ed. Gaithersburg, Maryland: AOAC, 2005.

MACHADO, L.C.; FERREIRA, W.M.; FARIA, H.G. et al. Avaliação da dieta simplificada com base em feno de alfafa para coelhas reprodutoras. Veterinária e Zootecnia, v.14, p.291-299, 2007.

MICHELAN, A.C.; SCAPINELLO, C.; FURLAN, A.C. et al. Utilização de casca de mandioca desidratada na alimentação de coelhos. Revista Acta Scientiarum Animal Science, v.28, n.1, p.31-37, 2006.

PEREIRA, J.R.A.; ROSSI, P. Manual prático de avaliação nutricional de alimentos. Piracicaba: FEALQ, 1995. 25p.

SCAPINELLO, C.; ANTUNES, E.B.; FURLAN, A.C. et al. Fenos de leucena (Leucaena leucocephala e Leucaena leucocephala cv. Cunningham) para coelhos em crescimento: digestibilidade e desempenho. Acta Scientiarum. Animal Sciences, v.25, n.2, p.301-306, 2003.

SCAPINELLO, C.; MICHELAN, A.C.; FURLAN, A.C. et al. Utilização da farinha de varredura da mandioca na alimentação de coelhos. Acta Scientiarum Animal Science, v.28, n.1, p.39-45, 2006.

SILVA, H.O.; FONSECA, R.A.; FILHO, R.S.G. Características produtivas e digestibilidade da farinha de folhas de mandioca em dietas de frangos de corte com e sem adição de enzimas. Revista Brasileira de Zootecnia, v.29, n.3, p.823-829, 2000.

SILVA, D.J.; QUEIROZ, A.C. Análises de alimentos: Métodos químicos e biológicos. 3.ed. Viçosa, MG: UFV, 2002. 235p.

STATISTICAL ANALYSES SYSTEM - SAS. SAS/STAT ${ }^{\circledR}$. User's guide: statistics. Versão 8.1, 4. ed., v.2, Cary: SAS Institute, 2000 . 